\title{
ASSISTED VENTILATION IN TERMINAL HYALINE MEMBRANE DISEASE*
}

BY

\author{
MARIA DELIVORIA-PAPADOPOULOS and PAUL R. SWYER \\ From The Research Institute of the Hospital for Sick Children, and the \\ Department of Paediatrics, University of Toronto. Canada
}

(RECEIVED FOR PUBLICATION MARCH 19, 1964)

Following the work of Donald (Donald and Young. 1952: Donald and Lord, 1953: Donald. 1954), reports are accumulating in the literature of the use of assisted ventilation in the treatment of the respiratory distress syndrome (RDS) (Donald, Kerr, and Macdonald, 1958; Benson, Celander, Haglund, Nilsson. Paulsen, and Renck, 1958; Benson and Celander, 1959; Stahlman, Young, and Payne, 1962: Heese, Wittmann, and Malan, 1963). Since the clinical and biochemical status immediately before the initiation of assisted ventilation has not been defined in detail, the purpose of this study has been to assess the potential of assisted ventilation in reversing the acidaemia of terminal and apparently hopeless cases of RDS.

\section{Materials and Methods}

The 18 infants studied were divided into three groups of 6 on the basis of duration of apnoea. cardiac condition, and type of cyanosis (Table 1). The corresponding blood chemistries are also shown in Table 1. All were continuously monitored electrocardiographically and had been receiving comparable treatment with glucose bicarbonate solution by infusion through a catheter placed in the inferior vena cava via the umbilical vein. since admission. All had failed to respond to generally accepted methods of resuscitation, including positive pressure manual ventilation by endotracheal tube which failed repeatedly to initiate and maintain spontaneous respiration.

The gestational ages and weights of the infants are shown in Table 2. The average weight of the infants in Group III is raised by the presence of two infants of diabetic mothers.

Immediately before intubation a sample of central venous blood was withdraun. Subsequent central venous samples were taken at intervals until death or recovery.

Ventilation was accomplished using Cole's endotracheal tubes in conjunction with a ventilator equipped with

* Supported by a grart from The Department of National Health and Welfare. Otiawa.

+ Bird Mark VIIl Respirator. Bird Corporation. Richmond. California. the minimal dead space $(0 \cdot 28 \mathrm{ml}$.) infant circle (S. Segal, 1963, personal communication).* Positive pressures used varied from 15 to $35 \mathrm{~cm}$.H.O. Where assisted ventilation was required for longer than 36-72 hours is (Cases Ly. and Ko.) a low tracheostomy was performed (Fearon, 1962) and ventilation continued through $\infty$ Hollinger tubes.

pH was measured by glass electrode, and $\mathrm{CO}$. content by means of the Kopp-Natelson-gasometer (Natelson, 1951: Holaday and Verosky, 1956), from simultaneous measurements of $p \mathrm{H}$ and $\mathrm{PCO}_{2}$ using a Severinghaus and Bradley (1958) type Pco, electrode. Blood buffer base was derived from the Singer and Hastings (1948) nomogram using simultaneously measured haematocrits. Measurements were made at $38^{\circ} \mathrm{C}$. and no correction was made for the infant's bcdy temperature. However, temperatures the time blocd samples were taken are given in Table

\section{Results}

The evolution of the acid-base status in the three groups is shown in Table 2 and Figs. 1 and 2.

Mean survival time on the ventilator was 1 hour for Group I, 10 hours for Group II, and 50 hours for Group III (Fig. 2). One infant (Ly) in Group III was ventilated for seven days and survived.

- Designed b: Dr Sydmey Segal (1963) and manufactured by the Bird
Corporation.

TABLE 1

INITIAL CLINICAL AND BIOCHEMICAL STATLS (VENOUS BLOOD) OF 18 INFANTS DIVIDED INTO THREE GROUPS OF 6 PATIENTS ON BASIS OF INCREASING SEVERITY

\begin{tabular}{|c|c|c|c|c|}
\hline Clinical Group & & I & II & III \\
\hline Respiratory arrest & $\ldots$ & 5 & Arrest $^{3}, 3$ & $\begin{array}{c}1 \\
\text { Arrest }\end{array}$ \\
\hline Heart . & & Arrest 3 & Rate 20 & Rate 60 \\
\hline 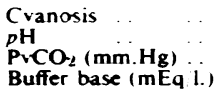 & $\begin{array}{l}\cdots \\
\cdots \\
\cdots\end{array}$ & $\begin{array}{c}\text { Paliid } \\
6.5 \\
100 \\
15.0\end{array}$ & $\begin{array}{c}\text { Mottling } \\
=6.75 \\
>100 \\
=20.0\end{array}$ & $\begin{array}{l}\text { Livid } \\
\times 6.75 \\
100 \\
=20.0\end{array}$ \\
\hline
\end{tabular}


TABLE

CLINICAL AND BIOCHEMICAL DATA NENOLS

\begin{tabular}{|c|c|c|c|c|c|c|c|c|c|c|c|c|c|c|c|c|c|}
\hline \multirow[b]{2}{*}{$\stackrel{\varrho}{\bar{\Sigma}}$} & \multirow[b]{2}{*}{$\stackrel{x}{x}$} & \multirow{2}{*}{ 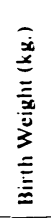 } & \multirow[b]{2}{*}{ 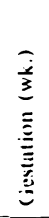 } & \multirow{2}{*}{ 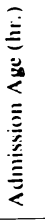 } & \multicolumn{4}{|c|}{$\begin{array}{l}\text { Immediately Before } \\
\text { ventilation }\end{array}$} & \multicolumn{7}{|c|}{$\begin{array}{c}20^{\circ} \text { ○ Ventilator } \\
\text { Life Span* }\end{array}$} & \multicolumn{2}{|c|}{$\begin{array}{l}40^{\circ} \text { Sentilator } \\
\text { Life Span* }\end{array}$} \\
\hline & & & & & 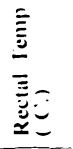 & ఏ & 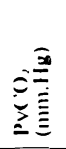 & 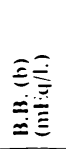 & 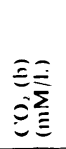 & 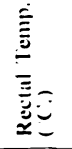 & 三 & 竞 & 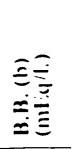 & $\begin{array}{l}\text { 严 } \\
\text { 棓 }\end{array}$ & 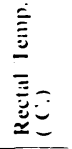 & 三 & 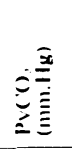 \\
\hline $\begin{array}{l}G r \\
\text { Ma } \\
\text { Mo } \\
\text { Fi. } \\
\text { Gi. } \\
\text { Br. } \\
\text { De. }\end{array}$ & 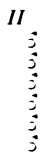 & $\begin{array}{l}2.9 \\
1.3 \\
2.0 \\
1.3 \\
1.6 \\
1.2\end{array}$ & $\begin{array}{l}39 \\
38 \\
36 \\
3.2 \\
32 \\
39\end{array}$ & $\begin{array}{r}12 \\
6 \\
10 \\
7 \\
45 \\
10\end{array}$ & $\begin{array}{r}36.5 \\
34.9 \\
35.4 \\
33.5 \\
35.4 \\
35.0\end{array}$ & $\begin{array}{l}6.75 \\
6.74 \\
6 \cdot 69 \\
6.62 \\
6.58 \\
6.66\end{array}$ & $\begin{array}{l}120 \\
125 \\
110 \\
140 \\
138 \\
135\end{array}$ & $\begin{array}{l}17.0 \\
17.5 \\
14.0 \\
15.0 \\
13.0 \\
14.0\end{array}$ & $\begin{array}{r}15.0 \\
166.0 \\
11 \cdot 0 \\
1.5 \\
9.5 \\
12.5\end{array}$ & $\begin{array}{l}36 \cdot 5 \\
34 \cdot 8 \\
35 \cdot 2 \\
33 \cdot 5 \\
35 \cdot 4 \\
34 \cdot 5\end{array}$ & $\begin{array}{l}7.05 \\
6.91 \\
6.88 \\
6.67 \\
7.07 \\
7.08\end{array}$ & $\begin{array}{l}35 \\
70 \\
54 \\
88 \\
36 \\
35\end{array}$ & $\begin{array}{l}26 \cdot 0 \\
26.0 \\
22.0 \\
14 \cdot 0 \\
27.0 \\
27.5\end{array}$ & $\begin{array}{r}18 \cdot 8 \\
14 \cdot 0 \\
10 \cdot 0 \\
9 \cdot 0 \\
10 \cdot 4 \\
9 \cdot 8\end{array}$ & $\begin{array}{l}35 \cdot 0 \\
35.6 \\
34 \cdot 5 \\
35.6 \\
34 \cdot 0\end{array}$ & $\begin{array}{l}7 \cdot 08 \\
7 \cdot 07 \\
6 \cdot 73 \\
7.10 \\
7.10\end{array}$ & $\begin{array}{l}48 \\
55 \\
84 \\
19 \\
35\end{array}$ \\
\hline $\begin{array}{l}\text { Gr } \\
\text { Ch. } \\
\text { La. } \\
\text { Ca. } \\
\text { Wi. } \\
\text { Ko. } \\
\text { Ly. }\end{array}$ & 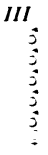 & $\begin{array}{l}3.9 \\
1.9 \\
3.1 \\
3.1 \\
1.4 \\
1.8\end{array}$ & $\begin{array}{l}40 \\
35 \\
37 \\
37 \\
30 \\
32\end{array}$ & $\begin{array}{r}8 \\
12 \\
24 \\
1 \\
8 \\
12\end{array}$ & $\begin{array}{r}35 \cdot 5 \\
35 \cdot 0 \\
35 \cdot 4 \\
35.0 \\
34 \cdot 8 \\
34 \cdot 9\end{array}$ & $\begin{array}{l}6.93 \\
6.91 \\
6.93 \\
6.99 \\
7.00 \\
6.77\end{array}$ & $\begin{array}{r}98 \\
100 \\
100 \\
95 \\
96 \\
110\end{array}$ & $\begin{array}{r}31 \cdot 0 \\
31.0 \\
31.0 \\
32.0 \\
33.0 \\
32.0\end{array}$ & $\begin{array}{r}20.0 \\
19.5 \\
20.8 \\
21.2 \\
22.0 \\
16.0\end{array}$ & $\begin{array}{l}37 \cdot 5 \\
36 \cdot 1 \\
36 \cdot 9 \\
36 \cdot 5 \\
36 \cdot 8 \\
36 \cdot 2\end{array}$ & $\begin{array}{l}7 \cdot 26 \\
7.34 \\
7.34 \\
7.36 \\
7.36 \\
7 \cdot 34\end{array}$ & $\begin{array}{l}34 \\
52 \\
42 \\
40 \\
40 \\
46\end{array}$ & $\begin{array}{l}38 \cdot 0 \\
48 \cdot 0 \\
44 \cdot 0 \\
46 \cdot 0 \\
43 \cdot 0 \\
47 \cdot 0\end{array}$ & $\begin{array}{l}14 \cdot 2 \\
25 \cdot 0 \\
20 \cdot 0 \\
19 \cdot 0 \\
20 \cdot 8 \\
21 \cdot 0\end{array}$ & $\begin{array}{r}37 \cdot 5 \\
37 \cdot 0 \\
36 \cdot 8 \\
37 \cdot 2 \\
38 \cdot 2 \\
37 \cdot 2\end{array}$ & $\begin{array}{l}7 \cdot 29 \\
6 \cdot 37 \\
7 \cdot 32 \\
7 \cdot 41 \\
7 \cdot 36 \\
7 \cdot 40\end{array}$ & $\begin{array}{l}38 \\
51 \\
51 \\
38 \\
45 \\
42 \\
42\end{array}$ \\
\hline
\end{tabular}

- Ventilator lite span tas detaled in the column cetore last has been froportioned to 100 to facilitate tabulation and comparison of the widel differing li:

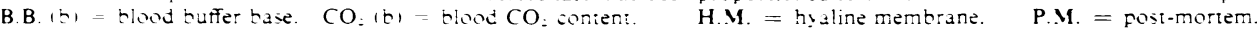

\section{Case Report}

Case Ly. This female infant was the third born of a 22-year-old mother. The gestation was 34 weeks and the birth weight $1.8 \mathrm{~kg}$. Within half an hour respirations became indrawing and grunting: these stmptoms worsened over the next $1^{-}$hours when she was transferred
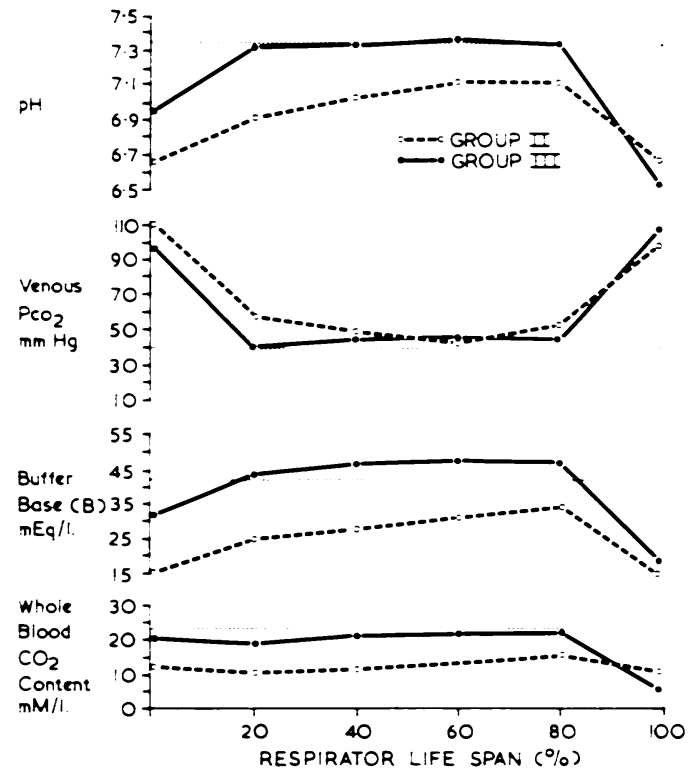

Fic. 1.-Average changes in acid-base measurements (renous blood 1 during positive pressure ventilation in Groups II and III. Patient Ly is excluded from the calculations for Group III tecause she survived with normal figures during her ventilator life span. to the Hospital for Sich Children. A radiograph at 18 hours showed a reticulo-granular pattern. Her condition then stabilized with $50 \%$ oxygen. at the neutral temperature. until at 35 hours she had a series of apnoeic spells

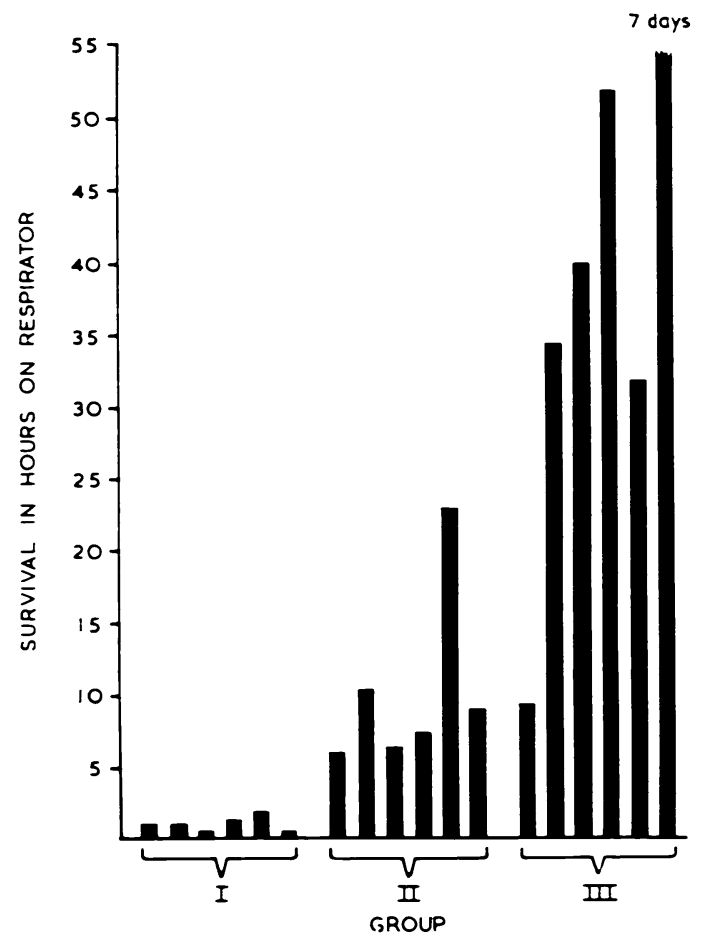

FIG. 2.-Survival in the three groufs. Patient Ly. in Grouf III was weaned from the respirator at dass and survised. 
2

\begin{tabular}{|c|c|c|c|c|c|c|c|c|c|c|c|c|c|c|c|c|c|c|}
\hline \multirow[b]{2}{*}{ 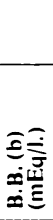 } & \multirow[b]{2}{*}{ 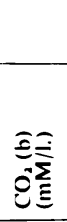 } & \multirow[b]{2}{*}{ 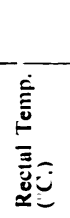 } & \multicolumn{3}{|c|}{$\begin{array}{l}60 \% \text { Ventilator } \\
\text { Life Span }\end{array}$} & \multirow[b]{2}{*}{$\begin{array}{l}\hat{E}= \\
\hat{O E}\end{array}$} & \multicolumn{4}{|c|}{$\begin{array}{l}80 \% \text { Ventilator } \\
\text { Life Span* }\end{array}$} & \multicolumn{5}{|c|}{$\begin{array}{c}\text { Terminal Stage on } \\
\text { Ventilator }\end{array}$} & \multirow{2}{*}{\multicolumn{2}{|c|}{ 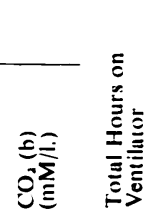 }} & \multirow[b]{2}{*}{$\sum_{a}^{\dot{a}}$} \\
\hline & & & I & 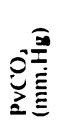 & 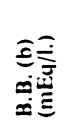 & & 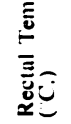 & I & 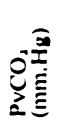 & 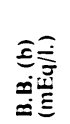 & 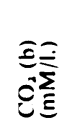 & 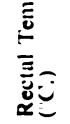 & $\bar{\Sigma}$ & 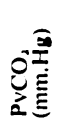 & 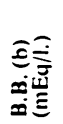 & & & \\
\hline $\begin{array}{l}\overline{30} \\
31 \\
18 \\
28 \\
28\end{array}$ & $\begin{array}{r}1 \overline{13 \cdot 4} \\
15 \cdot 0 \\
11 \cdot 5 \\
7 \cdot 0 \\
10 \cdot 0\end{array}$ & $\begin{array}{c}36 \cdot 8 \\
38 \cdot 2 \\
36 \cdot 0 \\
34 \cdot 6 \\
36 \cdot 0 \\
-\end{array}$ & $\begin{array}{c}7 \cdot 09 \\
7 \cdot 24 \\
7 \cdot 17 \\
6 \cdot 78 \\
7 \cdot 29 \\
-\end{array}$ & $\begin{array}{l}57 \\
29 \\
36 \\
72 \\
25 \\
-\end{array}$ & $\begin{array}{l}31 \cdot 5 \\
31 \cdot 0 \\
31 \cdot 0 \\
19 \cdot 0 \\
32 \cdot 0 \\
-\end{array}$ & $\begin{array}{l}16 \cdot 0 \\
11 \cdot 0 \\
12.0 \\
11.0 \\
11 \cdot 0 \\
-\end{array}$ & $\begin{array}{c}36 \cdot 0 \\
- \\
34 \cdot 0 \\
36 \cdot 8 \\
-\end{array}$ & $\begin{array}{c}7 \cdot 10 \\
- \\
7 \cdot 00 \\
7 \cdot 20 \\
-\end{array}$ & $\begin{array}{l}58 \\
\overline{-15} \\
35 \\
-\end{array}$ & $\begin{array}{c}32 \cdot 0 \\
\overline{-} \\
2 \overline{6} \cdot 0 \\
31 \cdot 5 \\
-\end{array}$ & $\begin{array}{c}17 \cdot 0 \\
- \\
10 \cdot 5 \\
12 \cdot 4 \\
-\end{array}$ & $\begin{array}{l}38 \cdot 0 \\
37 \cdot 3 \\
34 \cdot 6 \\
34 \cdot 0 \\
35 \cdot 8 \\
33 \cdot 0\end{array}$ & $\begin{array}{l}6 \cdot 70 \\
4 \cdot 80 \\
6 \cdot 60 \\
6 \cdot 87 \\
6 \cdot 60 \\
6 \cdot 73\end{array}$ & $\begin{array}{r}118 \\
98 \\
110 \\
100 \\
120 \\
100\end{array}$ & $\begin{array}{l}13 \\
22 \\
12 \\
18 \\
10 \\
15\end{array}$ & $\begin{array}{r}12 \cdot 2 \\
15 \cdot 0 \\
8 \cdot 0 \\
18 \cdot 0 \\
7 \cdot 8 \\
11 \cdot 0\end{array}$ & $\begin{array}{r}6 \cdot 0 \\
10 \cdot 5 \\
6 \cdot 5 \\
7 \cdot 5 \\
23 \cdot 0 \\
9 \cdot 0\end{array}$ & $\begin{array}{l}\text { H.M. } \\
\text { H.M. } \\
\text { H.M. } \\
\text { H.M. } \\
\text { H.M. } \\
\text { H.M. }\end{array}$ \\
\hline $\begin{array}{l}40 \\
50 \\
46 \\
49 \\
47 \\
46\end{array}$ & $\begin{array}{l}16 \cdot 5 \\
26 \cdot 0 \\
23 \cdot 0 \\
20 \cdot 0 \\
22 \cdot 5 \\
22 \cdot 5\end{array}$ & $\begin{array}{l}38 \cdot 0 \\
37 \cdot 0 \\
37 \cdot 5 \\
37 \cdot 1 \\
37 \cdot 5 \\
37 \cdot 0\end{array}$ & $\begin{array}{l}7 \cdot 32 \\
7 \cdot 39 \\
7 \cdot 46 \\
7 \cdot 45 \\
7 \cdot 28 \\
7 \cdot 34\end{array}$ & $\begin{array}{l}42 \\
50 \\
42 \\
36 \\
48 \\
46\end{array}$ & $\begin{array}{l}43 \cdot 0 \\
52 \cdot 0 \\
53 \cdot 0 \\
46 \cdot 0 \\
42 \cdot 0 \\
43 \cdot 0\end{array}$ & $\begin{array}{l}19 \cdot 8 \\
25 \cdot 4 \\
24 \cdot 8 \\
19 \cdot 5 \\
18 \cdot 1 \\
21 \cdot 5\end{array}$ & $\begin{array}{l}38 \cdot 0 \\
36 \cdot 5 \\
36 \cdot 6 \\
37 \cdot 3 \\
36 \cdot 8 \\
37 \cdot 4\end{array}$ & $\begin{array}{l}7 \cdot 34 \\
7 \cdot 37 \\
7 \cdot 34 \\
7 \cdot 40 \\
7 \cdot 36 \\
7 \cdot 40\end{array}$ & $\begin{array}{l}45 \\
50 \\
50 \\
42 \\
43 \\
42\end{array}$ & $\begin{array}{l}45 \cdot 0 \\
50 \cdot 0 \\
49 \cdot 0 \\
49 \cdot 0 \\
45 \cdot 0 \\
48 \cdot 0\end{array}$ & $\begin{array}{l}20 \cdot 8 \\
24 \cdot 0 \\
24 \cdot 0 \\
22 \cdot 0 \\
21 \cdot 2 \\
22 \cdot 5\end{array}$ & $\begin{array}{l}37 \cdot 0 \\
36 \cdot 4 \\
37 \cdot 0 \\
33 \cdot 6 \\
34 \cdot 5 \\
37 \cdot 8\end{array}$ & $\begin{array}{l}6 \cdot 69 \\
6 \cdot 70 \\
6 \cdot 58 \\
6 \cdot 70 \\
6 \cdot 64 \\
7 \cdot 36\end{array}$ & $\begin{array}{l}115 \\
120 \\
140 \\
110 \\
110 \\
44\end{array}$ & $\begin{array}{l}15 \\
15 \\
10 \\
13 \\
12 \\
46\end{array}$ & $\begin{array}{l}12 \cdot 0 \\
12 \cdot 5 \\
11 \cdot 0 \\
10 \cdot 5 \\
10 \cdot 0 \\
21 \cdot 5\end{array}$ & $\begin{array}{r}9 \cdot 5 \\
34 \cdot 5 \\
26 \cdot 0 \\
52 \cdot 0 \\
32 \cdot 0 \\
146 \cdot 0\end{array}$ & $\begin{array}{c}\text { H.M. } \\
\text { H.M. } \\
\text { H.M. } \\
\text { H.M. } \\
\text { H.M. } \\
\text { Survived }\end{array}$ \\
\hline
\end{tabular}

spans in real time.

which responded to stimulation ard $100^{\circ}$ oxygen by face-mask. At 49 hours she ceased to breathe and the heart rate fell to 50 a minute. She failed to respond to positive pressure respiration by face mask. An endotracheal tube was therefore inserted and assisted ventilation begun at $35 \mathrm{~cm}$. $\mathrm{H}_{2} \mathrm{O}$ positive pressure. While the electrocardiogram was monitored $10 \mathrm{mEq} \mathrm{NaHCO}_{3}$ (half the calculated buffer base deficit) was injected slowly through the umbilical vein. There was an immediate and sustained improvement in clinical status, coincidental with correction in both respiratory and metabolic components of the acidosis. A low tracheostomy was performed (Dr Blair Fearon) at 73 hours and following a gradual reduction in pressure from 40 to $25 \mathrm{~cm}$. $\mathrm{H}_{2} \mathrm{O}$, assisted ventilation was discontinued at 9 days. The tracheostomy tube was removed on the 14 th day. Progress was complicated by an intercurrent pneumonic infection which responded to antibiotic treatment. The infant was discharged home on the 47 th day with minimal perihilar infiltraticn radiologically, no abnormal symptoms or physical signs, and weighing $2,800 \mathrm{~g}$. Examination at 6 months of age disclosed no neurological or other abnormality, ard the chest radiograph was normal. More prolonged follow-up will be required to assess her development.

Necropsy in Group I showed hyaline membrane disease with superimposed massive pulmonary haemorrhage. The fatal cases in Groups II and III showed uncomplicated hyaline membrane disease only.

\section{Discussion}

The results show a clear-cut difference in survival times in the three groups which can be correlated with the initial clinical and biochemical status and with the type and degree of biochemical correction.

Infants in the worst condition (Group I) evinced no appreciable clinical or biochemical response. The necropsy finding of massive pulmonary haemorrhage associated with hyaline membranes explains the failure of assisted ventilation to achieve gas exchange.

Infants whose initial condition was somewhat better (Group II) made a rapid correction of their respiratory acidosis but buffer-base levels were relatively unchanged, in fact mean $p \mathrm{H}$ levels did not rise above $7 \cdot 11$ (Fig. 1). In contrast infants in Group III corrected both the respiratory and the metabolic components of their acidaemia so that $p \mathrm{H}$ reached normal levels usually within three hours of starting assisted ventilation.

In 5 out of the 6 infants who achieved complete correction, clinical and biochemical deterioration eventually took place after a varying pariod during which a normal acid-base status was maintained. This final deterioration was relatively rapid, occurring usually over a three-hour period.

It seems that if the stage of clinical death is not too far advanced the condition is potentially reversible. Thus patients in Groups I and II were in late and irreversible stages of clinical death. This is selfevident for Group I patients. In Group II infants, failure to correct metabolic acidosis in spite of a satisfactory lowering of (venous) Pco, in 5 of the 6 patients suggests the possibility of an irreversible degree of biological cellular damage with metabolic failure. 
On the other hand the complete correction maintained on assisted ventilation for many hours in Group III suggests that death before ventilation results from neuromuscular respiratory failure in the presence of sufficient gas exchange surface to support life. This, then, provides the rationale for assisted ventilation.

Our results suggest that the best hope of success with this treatment lies in its application in the preterminal rather than in the terminal state.

\section{Summary}

Eighteen apnoeic infants dying from the respiratory distress syndrome have been treated by positive pressure assisted ventilation. The infants were divided into three groups of increasingly advanced clinical death on the basis of duration of respiratory arrest, cardiac status, and type of cyanosis. Initial acid-base state and its changes during treatment were recorded. The duration of survival was related to the severity of the clinical and biochemical condition when ventilation was begun. Only in the least advanced group was significant prolongation of life (average 50 hours) and complete correction of metabolic and respiratory acidosis achieved. One infant in this group survived apparently undamaged.

We thank Dr. C. E. Snelling, Dr. J. A. P. Turner, and members of the staff of The Hospital for Sick Children, for permitting us to treat infants under their care; Dr. S. H. Jackson, Mr. R. Davidson, and Mr. J. Fabenyi for biochemical advice and estimations; Dr. Blair Fearon for performing tracheostomies in premature subjects; Miss Lynn Shoemaker and the nursing staff of the Neonatal Unit; Mr. D. McIntosh for technical help and Miss Carol MacLennan for secretarial assistance.

\section{REFERENCES}

Benson. F.. and Celander. O. (1959). Respirator treatment of pulmonary insufficiency in the newborn. Acta paediat. (Lppsala). 48. Suppl. 118. 49.

- _. Haglund. G., Nilsson. L.. Paulsen. L.. and Renck. L. (1958). Positive-pressure respirator treatment of severe pulmonary insufficiency in the newborn infant. A clinical report. Acto anaesth. scand., 2. 37.

Donald. 1. (1954). Augmented respiration: An emergency positivepressure patient-cycled respirator. Lancet, 1, 895.

. Kerr. M. M.. and Macdonald. I. R. (1958). Respiratory phenomena in the newbor $n$ : experiments in their measurement and assistance. Scot. med. J., 3. 151.

- and Lord. J. (1953). Augmented respiration: Studies in atelectasis neonatorum. Lancet. 1.9.

. and Young, I. M. (1952). An automatic respiratory amplifier J. Physiol. (Lond.), 116, $41 \mathrm{P}$

Fearon. B. (1962). Acute laryngotracheobronchitis in infancy and childhood. Pediat. Clin. N. Amer., 9. 1095.

Heese, H. de V., Wittmann, W.. and Malan. A. F. (1963). The management of the respiratory distress of the newborn with positive-pressure respiration. S. Afr. med. J.. 37.123.

Holaday, D. A.. and Verosky, M. (1956). Improved micromanometric methods for the analysis of respiratory gases in plasma and whole blood. J. Lab. clin. Med.. 47, 634.

Natelson, S. (1951). Routine use of ultramicro methods in the clinical laboratory. Amer. J. clin. Path.. 21. 1153.

Severinghaus, J. W., and Bradky. A. F. (1958). Electrodes for blood $\mathrm{PO}_{2}$ and $\mathrm{PCO}_{2}$ determination. J. appl. Physiol., 13. 515.

Singer, R. B., and Hastings, A. B. (1948). An improved clinical method for the estimation of disturbances of the acid-base balance of human blood. Medicine (Baltimore), 27, 223.

Stahlman, M.. Young. W.. and Payne, G. (1962). Studies of ventilatory aids in hyaline membrane disease. Amer. J. Dis. Child., 104. 526. 